\title{
Contents, Vol. 29, 1997
}

\section{No. 1}

No. 2

\section{Original Papers}

1 Evidence against Cannabinoid Receptor Involvement in Intraocular Pressure Effects of Cannabinoids in Rabbits

Hodges, L.C. (Decatur, Ga.); Reggio, P.H. (Kennesaw, Ga.); Green, K. (Augusta, Ga.)

6 Venous Tone in Glaucoma and Hypertension

Bojic, L.; Sardelic, S.; Bagatin, J.; Hozo, I.; Stanic, R.; Ivanisevic, M. (Split); Cerovski, B.

(Zagreb)

12 Vascular Changes in Retinas of Spontaneously Hypertensive Rats Demonstrated by Corrosion Casts

Bhutto, LA.; Amemiya, T. (Nagasaki)

24 In situ Localization of Basic Fibroblast Growth Factor Protein and mRNA in the Retina

Ohsato, M.; Hayashi, H.; Oshima, K. (Fukuoka); Koji, T.; Nakane, P. (Nagasaki)

31 Retinal Pigment Epithelium Cells Promote the Maturation of Monocytes to Macrophages in vitro

Osuský, R. (Los Angeles, Calif./Basel); Malik, P.; Ryan, S.J. (Los Angeles, Calif.)

37 Copper-Ion-Catalyzed Vitreous Liquefaction in vivo

Akiba, J.; Yanagiya, N,; Kakehashi, A.; Hikichi, T.; Kado, M.; Yoshida, A. (Asahikawa); Ueno, N. (Osaka)

42 Mineralocorticoid Receptors in the Rabbit Iris-Ciliary Body

Schwartz, B.; Wysocki, A. (Boston, Mass.)

48 Ultrastructural Study of Axonal Cytoskeletons in the Optic Nerve Damaged by Acutely

Elevated Intraocular Pressure Using the Quick-Freezing and Deep-Etching Technique

Ou, B.; Ohno, S.; Terada, N; Fujii, Y.; Ueda, H.; Chen, H.-B.; Tsukahara, S. (Yamanashi)

Original Papers

57 Effect of Consecutively Applied Fluorescein Eye Drops on Corneal and Aqueous

Concentrations of Fluorescein

Linden, C. (Umeå); Aim, A. (Uppsala)

61 Effects of Mucin Ophthalmic Solution on Epithelial Wound Healing in Rabbit Cornea

Shigemitsu, T.; Shimizu, Y.; Majima, Y. (Aichi)

67 Influence of Tissue Sample Dimensions on the Swelling of the Corneal Stroma

Aakre, B.M.; Doughty, M.J. (Glasgow) 75 In vitro UV-B Effect on Lens Protein Solutions

Wu, K.; Kojima, M,; Shui, Y.B.; Sasaki, K.; Hockwin, O. (Uchinada)

83 Possible Mechanism of Exacerbating Cataract Formation in Cataractous Human Lens

Capsules Induced by Systemic Hypertension or Glaucoma

Lee, S.-M.; Lin, S.-Y.; Li, M.-J.; Liang, R.-C. (Taipei)

91 In vitro Effects of Doxorubicin and Mitomycin C on Human Tenon's Capsule Fibroblasts 
Saika, S,; Ooshima, A.; Yamanaka, O. (Wakayama); Kimura, M. (Osaka); Okada, Y,; Tonoe, O.; Tanaka, S.; Ohnishi, Y. (Wakayama)

103 Flow C $\gamma$ tometric Analysis of Surface Antigens on Human Conjunctival Epithelial Cells Fujihara, T. (Chiba/Nara); Takeuchí, T.; Saito, K. (Saitama); Tsubota, K. (Chiba)

110 Diurnal Variations in Intraocular Pressure in the Albino Rabbit: Relationship to Morning Intraocular Pressure

Bar-Han, A. (Gainesville, Fla./Rehovot); Beilin, M. (Rehovot)

Acknowledgment to Referees

Announcements

$\mathrm{KAIU}$;EH

E-Mail karger@karger.ch Fax+41 613061234 http://www.karger.ch

(C) 1997 S. KargerAG. Basel

The list of contents is available at: http://www.karger.ch/journals/ore/orecont.htm

No. 3

Original Papers

117 A New Chromatographic Method for Measurement of Rubidium Transport Activities in Cultured Bovine Retinal Pigment Epithelial Cells

Crider, J.Y.; Williams, G.W.; Yorio, T.; Sharif, N.A.; Griffin, B.W. (Fort Worth, Tex.)

124 Monocyte-Macrophage Differentiation Induced by Coculture of Retinal Pigment Epithelium Cells with Monocytes

Osuský, R. (Los Angeles, Calif./Basel); Malik, P.; Aurora, Y.; Ryan, St.J. (Los Angeles, Calif.) 130 Vascular Expression of Endothelial Antigen PAL-E Indicates Absence of Blood-Ocular Barriers in the Normal Eye

Schlingemann, R.O.; Hofman, P. (Amsterdam); Andersson, L. (Uppsala); Troost, D.; van der Gaag, R. (Amsterdam)

139 Effect of Timolol and UF-021 (a Prostaglandin-

Related Compound) on Pulsatile Ocular Blood Flow in Normal Volunteers

Kitaya, N,; Yoshida, A.; Ishiko, S.; Mori, F.; Abiko, T.; Ogasawara, H.; Kato, Y.; Nagaoka, T. (Asahikawa)

145 Combined Non-Steroidal Therapy in Experimental Corneal Injury

Laria, C; Alió, J.L.; Ruiz-Moreno, J.M. (Alicante)

154 Histochemical Study of Leukocyte Elastase Activity in Alkali-Burned Rabbit Cornea

Cejková, J. (Prague)

161 The Cryner Element in the Murine $\gamma$-Crystallin Promoters Interacts with Lens Proteins

Stöger, T. (Neuherberg); Augusteyn, R.C. (Carlton); Graw, J. (Neuherberg)

172 Polycyclic Aromatic Hydrocarbons in Bovine Lens

Gallenga, P.E.; Morgante, A.; Ciancaglini, M.; Petti, L. (Chieti); Costagliola, C. (Naples);

Carpíneto, P.; Mastropasqua, L. (Chieti)

No. 4

Original Papers

177 Towards a Human Crystallin Map. Two-Dimensional Gel Electrophoresis and Computer Analysis of Water-Soluble Crystallinsfrom Normal and Cataractous Human Lenses

Bloemendal, H.; Van de gaer, K. (Nijmegen); Benedetti, EX.; Dunia, I. (Paris); Steely, H.Th. (Fort Worth,Tex.)

191 Liquid Chromatography/Mass-Spectrometric Characterization of Sphingomyelin and Dihydrosphingomyelin of Human Lens Membranes 
Byrdwell, W.C. (Peoria, 111.); Borchman, D. (Louisville, Ky.)

207 Some Plasma Constituents Correlate with Human Cataract Location and Nuclear Colour Donnelly, C.A. (Oxford); Seth, J.; Clayton, R.M.; Phillips, C.I.; Cuthbert, J. (Edinburgh)

218 Effects of Different Formulations of Mitoxantrone (Solutions, Nanospheres, Liposomes) on

Glaucoma Surgery in Rabbits

Tilleul, P.; Denis, P.; Maignen, F. (Paris); Elena, P.P.

(La Gaude); Nordmann, J.P.; Leverge, R.; Rostène, W. (Paris)

227 Concomitant Treatment with a 5-Lipoxygenase Inhibitor Improves the Anti-Inflammatory

Effect of the Inhibition of Nitric Oxide Synthase during the Early Phase of Endotoxin-lnduced Uveitis in the Rabbit

Bellot, J.L.; Palmero, M. (Barcelona); Alcoriza, N.; Blanco, A.; García-Cabanes, C. (Alicante); Hariton, C. (Basel); Orts, A. (Alicante)

No. 5

Diseases of the Retina

Editors: Wiedemann, P.; Kohen, L. (Leipzig)

$241 \quad$ Editorial

Wiedemann, P.; Kohen, L. (Leipzig)

242 Ocular Gene Therapy: Experimental Studies and

Clinical Possibilities

Murata, T.; Kimura, H.; Sakamoto, T.; Osusky, R.; Spee, C; Stout, T.J.; Hinton, D.R.; Ryan, S.J. (Los Angeles, Calif.)

252 Molecular Elucidation of Hereditary Eye Diseases: Pivotal Role of the Clinician

Ropers, H.H. (Nijmegen/Berlin)

261 Gene Therapy for Retinal Degeneration

Reichel, M.B. (Leipzig/London); Ali, R.R.; Hunt, D.M.; Bhattacharya, S.S. (London)

269 The Development of Subretinal Microphotodiodes for Replacement of Degenerated

Photoreceptors

Zrenner, E.; Miliczek, K.-D. (Tubingen); Gabel, V.P. (Regensburg); Graf, H.G. (Stuttgart);

Guenther, E.; Haemmerle, H. (Tubingen); Hoefflinger, B. (Stuttgart); Kohler, K.; Nisch, W.

(Tubingen); Schubert, M. (Stuttgart); Stett, A.; Weiss, S. (Tubingen)

281 Learning Retina Implants with Epiretinal Contacts

Eckmiller, R. (Bonn)

290 Photoreceptor Transplants Increase Host Cone Survival in the Retinal Degeneration (rd)

Mouse

Mohand-Said, S.; Hicks, D.; Simonutti, M.; Tran-Minh, D.; Deudon-Combe, A.; Dreyfus, H.

(Strasbourg); Silverman, M.S.; Mosinger Ogilvie, J.; Tenkova, T. (St. Louis, Mo.); Sahel, J.

(Strasbourg)

298 Mechanisms of Graft Rejection in the Transplantation of Retinal Pigment Epithelial Cells

Kohen, L.; Enzmann, V.; Faude, F.; Wiedemann, P. (Leipzig)

305 Intraretinal Transplantation to Prevent Photoreceptor Degeneration

Lund, R.D. (London); Coffey, P J. (Sheffield); Sauvé, Y.; Lawrence, J.M. (London)

320 Blood Supply of the Retina

Funk, R.H.W. (Dresden)

326 The Müller (Glial) Cell in Normal and Diseased Retina: A Case for Single-Cell

Electrophysiology 
Reichenbach, A.; Faude, F,; Enzmann, V.; Bringmann, A.; Pannicke, T.; Francke, M.;

Biedermann, B.; Kuhrt, H.; Stolzenburg, J.-U. (Leipzig); Skatchkov, S.N. (Bayamon, P.R.);

Heinemann, U. (Berlin); Wiedemann, P.; Reichelt, W. (Leipzig)

Contents

Ophthalmic Res Vol. 29, 1997

III

341 Growth Factors in Age-Related Macular Degeneration: Pathogenic and Therapeutic

Implications

Frank, R.N. (Detroit, Mich.)

354 Vascular Endothelial Growth Factor and the Eye: Biochemical Mechanisms of Action and Implications for Novel Therapies

Aiello, L.P. (Boston, Mass.)

409 Evaluation of Collagen Gel and Hyaluronic Acid as Vitreous Substitutes

Nakagawa, M.; Tanaka, M.; Miyata, T. (Tokyo)

421

Ibuprofen Protects Alpha-Crystallin against Posttranslational Modification by Preventing Protein Cross-Linking

Plater, MX.; Goode, D.; Crabbe, M.J.C. (Reading)

429

Determination of Water Content in Bovine Lenses Using Near-Infrared Spectroscopy

Zink, J.M. (Wooster, Ohio); Koenig, J.L. (Cleveland, Ohio); Williams, T.R. (Wooster, Ohio)

No. 6

Obituary

Original Papers

365 Sites of Disruption of the Blood-Aqueous Barrier after Application of Prostaglandin E2 in Pigmented Rabbits

Kadoi, C; Hiraki, S.; Hayasaka, S,; Ohtani, O. (Toyama)

374 Visualization and Flow of Platelets and Leukocytes in vivo in Rat Retinal and Choroidal

Vessels

Kim, J.; Yang, Y,; Shin, B,; Cho, C. (Chonbuk)

381 Antibody Alone Does Not Prevent Experimental Cytomegalovirus Retinitis in Mice with

Retrovirus-Induced Immunodeficiency (MAIDS)

Dix, R.-D.; Cray, C; Cousins, S.W. (Miami, Fla.)

393 Repair of Retinal Pigment Epithelium and

Choriocapillaries after Laser Photocoagulation: Correlations between Scanning Electron,

Transmission Electron and Light Microscopy

Pollack, A.; Korte, G.E. (New York, NY.)

405 Topical Cyclosporin as an Adjunct to Topical

Acyclovir Treatment in Herpetic Stromal Keratitis

Gündüz, K.; Özdemir, 0. (Ankara)

436 Ingo Weisse $\uparrow$, Dr. med. vet. Hockwin, O. (Bonn)

438 Author Index 440 Subject Index

Suppl. 1 
JERMOV 97: Joint European Research Meeting in Ophthalmology and Vision

October 15-19,1997, Montpellier, France

Guest Editor: L. Missotten, Leuven, Belgium

\section{KARGER}

\section{S. Karger}

Medical and Scientific Publishers Basel · Freiburg · Paris · London New York · New Delhi · Bangkok Singapore $\cdot$ Tokyo $\cdot$ Sydney

Drug Dosage

The authors and the publisher have exerted every effort to ensure that drug selection and dosage set forth in this text are in accord with current recommendations and practice at the time of publication. However, in view of ongoing research, changes in government regulations, and the constant flow of information relating to drug therapy and drug reactions, the reader is urged to check the package insert for each drug for any change in indications and dosage and for added warnings and precautions. This is particularly important when the recommended agent is a new and/or infrequently employed drug.

All rights reserved.

No part of this publication may be translated into other languages, reproduced or utilized in any form or by any means, electronic or mechanical, including photocopying, recording, microcopying, or by any information storage and retrieval system, without permission in writing from the publisher or, in the case of photocopying, direct payment of a specified fee to the Copyright Clearance Center (see 'General Information').

(C) Copyright 1997 by S. Karger AG, P.O. Box, CH-4009 Basel (Switzerland) Printed in Switzerland on acid-free paper by Reinhardt Druck. Basel

IV

Ophthalmic Res Vol. 29, 1997

Contents 